\title{
Field susceptibility of 13 scab-resistant apple cultivars to apple powdery mildew [Podosphaera leucotricha (Ell. et Ev.) Salmon]
}

\section{ZBIGNIEW BORECKI}

\author{
Department of Plant Pathology, Warsaw Agricultural University, \\ ul. Nowoursynowska 166, 02-700 Warsaw, Poland
}

(Received: September 22, 1986)

\begin{abstract}
Field susceptibility of 13 scab-resistant apple cultivars to apple powdery mildew was evaluated in 1983-1986. Four groups of susceptibility were distinguished. None of the 13 tested scab-resistant apple trees exhibited complete field immunity to apple powdery mildew. Two cultivars, 'Prima' and 'Primula', were practically resistant. 'Liberty' and two numbered selections, NY-140-9 and NY-158-2, belonged to the group of lower susceptibility. Moderate susceptibility was shown by: 'Novamac', 'Freedom', 'Gavin', 'Prima' and 'Florina'. The group of apple trees most susceptible to Podosphaera leucotricha included: 'Macfree', 'Priscilla' and 'Nova Easygro'. It is not necessary to use chemical sprays to control powdery mildew on 'Prima' and 'Primula'. A reduced spraying program may be recommended only under high disease pressure on less susceptible apple cultivars. A regular spray schedule is needed on moderately susceptible apple trees, but improved chemical control is necessary on the most susceptible ones.
\end{abstract}

\section{INTRODUCTION}

The fungi, Venturia inaequalis and Podosphaera leucotricha, are the most important apple tree pathogens, and their control requires repeated spraying with fungicides. The breeding of apple cultivars resistant to scab has made it possible to reduce the number of sprays, or to completely abandon them, especially when these cultivars also show sufficient resistance to mildew.

Most authors think that no cultivar is completely resistant to mildew (H e a ld, 1933; A l s to n, 1969; S p r a g u e, 1953). In Germany, S c ha nd e r (1958) conducted detailed studies on the susceptibility of apple cultivars to mildew and selected resistant seedlings. The most extensive study on this subject was presented in England in 1968 by Alston, who evaluated the susceptibility of 2.139 apple cultivars. Using a 6 point 
grading system, he was not able to find any cultivars with grade 0 (field immune) or grade 1 susceptibility (occasional minute infected areas up to $2 \mathrm{~mm}$ in diameter). Most of the cultivars showed moderate susceptibility, significantly fewer showed high or very high susceptibility. The group of cultivars very lightly infected (grade 2) included, among others, 'Hibernal', 'Haralson', 'Democrat' and 'Prinz Albrecht von Preussen'. 'Antonówka', 'Delicious', 'Red Delicious', 'Starking', 'Starkrimson' and 'Spartan' were in the lightly infected group. Alston classified as moderately susceptible (grade 4): 'Golden Delicious', 'Idared', 'James Grieve', 'McIntosh' and 'Wealthy'; as highly susceptible (degree 5): 'Cortland', 'Jonathan', 'Grimes Golden', 'Mutsu' and 'Granny Smith'. Only two of the over 2000 cultivars studied were found in the group with the highest susceptibility, 'Holstein' and 'Irish Peach'.

Ald winckle (1974) also presented a comprehensive study on the susceptibility of apple cultivars to mildew, using a simple, 4 point grading system. Among the most resistant cultivars are, according to this author, 'Golden Delicious', 'McIntosh', 'Wealthy', 'Empire', 'Macoun' and 'Lodi', as well 'Mutsu' and 'Grimes Golden', which A ls t o n classified as susceptible. The information given by Aldwinckle (1979) about infection by mildew of cultivars resistant to the fungus, Venturia inaequalis, is of considerable interest. Using a simplified, three point scale, he assigned to the most susceptible group: 'Priscilla', 'Priam', 'Nova Easygro' and 'Florina'. 'Prima', 'Sir Prize' and 'Liberty' were in the group of moderately resistant cultivars. This opinion about 'Liberty' has been confirmed in its description, in which the authors stated that during over twenty-year long observations, 'Liberty' was less infected with mildew than 'McIntosh' (L a m b et al., 1978).

In a comprehensive pomological study, $R$ e $j \mathrm{~m}$ a $n$ (1976) presents and evaluation of cultivars, distinguishing four rates of resistance to apple mildew. Highly resistant, according to him, are 'Antonówka', 'Boskoop', 'Close', 'Inflancka', 'James Griev', 'Melba Red', 'Spartan', 'Starking' and 'Wealthy'. Practically resistant are: 'Lobo', and 'Oberländer Himbeerapfel', moderately resistant - 'Cox's Orange Pippin', 'Landsberger Renette' and 'McIntosh', little resistant are: 'Boiken', 'Cortland', 'Idared' and 'Jonathan'.

Many authors have worked on the genetic resistance of apple trees to powdery mildew. Knight and A lst on (1968) found a single dominant gene - $\mathrm{Pl}_{1}$ in the apple, Malus robusta, and gene $\mathrm{Pl}_{2}$ in Malus zumi. Similar studies have been done by $\mathrm{W}$ atkins (1974) and $\mathrm{M}$ is ic (1966). McIntosh and Lapins (1966) found significant differences in the degree of susceptibility among 21 clones of the 'McIntosh' cultivar after subjecting it to radiation; Mow ry (1965) found that resistance to mildew is goverened by a single gene and inherited independently 
of apple scab resistance. Further studies, conducted mainly at East Malling, have not confirmed the view on the monogenic resistance of apple trees to mildew (A $1 \mathrm{ston}, 1969$ ). A similar opinion was voiced earlier by Brown (1959), who did not find a clear influence of a dominant gene on the degree of resistance to mildew. By selection of apple seedlings, Dayton (1977) obtained forms completely resistant to the fungus, Podosphaera leucotricha. These seedlings made very interesting breeding material. Siebs (1959) worked on the problems of variability of the fungus, Podosphaera leucotricha, its races, methods of artificial inoculation and in vitro culture.

A ldwinckle (1974) linked the grade of resistance of apple trees to powdery mildew with the intensity of chemical control. He distinguished four classes of resistance: 1) resistant cultivars - no sprays for mildew are needed, 2) slightly susceptible cultivars which can be treated according to a reduced spraying program, 3) moderately susceptible cultivars needing protection as provided by the regular recommended spray schedules, 4) highly susceptible cultivars whose protection under severe disease conditions demands an intense spraying program. Similar changes in the spraying program according to the susceptibilty of the apple cultivar have been recommended by $\mathrm{B} u t t$ (1979).

\section{MATERIAL AND METHODS}

Observations on the susceptibility of 13 scab-resistant apple cultivars were conducted in 1983-1986 in the experimental orchard of the Warsaw Agricultural University at Wilanów. Observed were apple trees planted in the autumn of 1980 and spring of 1981. All of the cultivars were completely resistant to apple scab. Twelve of the cultivars were from the breeding line Vf (Malus floribunda) and one, Nova Easygro, from line Vr (Malus pumila). The apple trees grew on fertile fen soil in Wilanów, budded on 'Antonówka' seedlings, had very favorable conditions for development. Standard fertilization and cultivation was employed in the orchard. The experimental trees were not sprayed with fungicides, and only if pests began to appear, were zoocides against aphids and mites used, not more often, however, than twice per season.

The susceptibility of the cultivars to mildew was determined on the basis of three indexes, the most important of which was the grade of leaf infection, determined as the leaf surface (in percen't) covered by apple powdery mildew. The infection of leaves was evaluated four times during the experiment, on average every 20 days - at the beginning and end of June, in mid...July and at the beginning of August. It was accepted that the most conclusive results were from mid-July when the disease attained its highest intensity and the leaves had not yet been 
severely deformed. On each of the 12 trees of one cultivar, the infection of leaves on all of this year's shoots was evaluated according to the modified grading scale of B ore cki and Burkowicz (1963). According to this scale, the successive stages of infection corresponded with the following values expressing the percent of the leaf surface covered with powdery mildew:

1 - very little susceptible: single leaves covered by apple powdery mildew, $1 \%$ on average;

2 - slightly susceptible: from 1 to $10 \%$ of the leaf surface covered with apple powdery mildew, $5 \%$ on average;

3 - moderately susceptible: from 11 to $30 \%$ of the leaf surface covered with apple powdery mildew, $20 \%$ on average;

4 - rather susceptible: from 31 to $50 \%$ of the leaf surface covered with apple powdery mildew, $40 \%$ on average;

5 - highly susceptible: over $51 \%$ of the leaf surface covered with apple powdery mildew, $75 \%$ on average.

The second index of susceptibility of apple cultivars was the percent of shoots infected by the fungus, Podosphaera leucotricha, determined at the beginning of August. The infection of all of the shoots, whose number starting from 1984 exceeded 100 per tree, was determined. The number of shoot in 1983 on 'Novamac' and 'Nova Easygro' cultivars was somewhat lower. The third index of susceptibility was the percent of apples damaged by powdery mildew causing russesting of the surface of the fruit. A random sample of 100 apples was taken from each tree. In 1983, the sample from trees of the 'Novamac' and 'Nova Easygro' cultivars was smaller, since the trees from these cultivars were just beginning to bear fruit. One tree made up a repetition, and the whole experiment had 13 treatments (the number of cultivars) and 12 repetitions (the number of trees of each cultivar). The results were analysed statistically by the method of variance analysis and the significance of the differences was evaluated by Duncan's test at the level $\mathrm{L}=0.05$.

\section{RESULTS}

During the four years of observations, large differences in the degree of infection of the apple cultivars were found in the successive years. The mild winters from 1980 to 1983 promoted the gradual intensification of the mildew epidemic, which attained its height in 1984 (Table 1, 2). During the following seasons, the epidemic partially died down due to the very cold winters of $1984 / 1985$ and 1985/1986 (Tables 3, 4).

Sufficient resistance to powdery mildew was exhibited by only two cultivars, 'Prima' and its sister seedling 'Primula'. In the group of slightly susceptible apple trees were trees from the numbered selection NY 55- 
Table 1

Susceptibility of apple cultivars to apple powdery mildew (Podosphaera leucotricha). Wilanów 1983

\begin{tabular}{|c|c|c|c|c|c|c|}
\hline \multirow{2}{*}{ Cultivar } & \multirow{2}{*}{$\begin{array}{c}\text { Percent of infected } \\
\text { shoots } 3.03\end{array}$} & \multicolumn{4}{|c|}{ Percent of leaf surface covered by apple powdery mildew on the days } & \multirow{2}{*}{$\begin{array}{l}\text { Percent of infected } \\
\text { fruits } 3.08\end{array}$} \\
\hline & & 3.05 & 22.06 & 12.07 & 3.03 & \\
\hline 'Primula' & 0 & $0.01 \mathrm{a}$ & $0.01 \mathrm{a}$ & $0.02 \mathrm{a}$ & $0.02 \mathrm{a}$ & 0 \\
\hline 'Frima' & 0 & $0.02 \mathrm{a}$ & $0.02 \mathrm{a}$ & $0.04 \mathrm{a}$ & $0.04 \mathrm{a}$ & 0 \\
\hline NY 55-158-2 & $11.07 \mathrm{a}$ & $1.17 \mathrm{~b}$ & $3.01 \mathrm{~b}$ & $3.11 \mathrm{~b}$ & $3.19 \mathrm{~b}$ & 0 \\
\hline 'Liberty Sister' & $13.25 \mathrm{a}$ & $1.23 \mathrm{~b}$ & $3.13 \mathrm{~b}$ & $3.17 \mathrm{~b}$ & $4.01 \mathrm{~b}$ & 0 \\
\hline 'Liberty' & $18.91 \mathrm{ab}$ & $2.61 \mathrm{~b}$ & $5.86 \mathrm{~b}$ & $6.21 \mathrm{~b}$ & $6.03 \mathrm{~b}$ & 0 \\
\hline 'Novamac' & $16.51 \mathrm{a}$ & $3.58 \mathrm{~b}$ & $4.02 \mathrm{~b}$ & $4.73 \mathrm{~b}$ & $5.24 \mathrm{~b}$ & 0 \\
\hline 'Gavin' & $29.12 \mathrm{~b}$ & $6.96 \mathrm{c}$ & $7.35 \mathrm{c}$ & $10.51 \mathrm{c}$ & $13.53 \mathrm{c}$ & $2.86 \mathrm{a}$ \\
\hline 'Priam' & $35.13 \mathrm{c}$ & $9.58 \mathrm{c}$ & $16.23 \mathrm{~d}$ & $18.16 \mathrm{~d}$ & $19.21 \mathrm{~d}$ & $3.14 \mathrm{a}$ \\
\hline 'Florina' & $37.08 \mathrm{c}$ & $6.36 \mathrm{c}$ & $9.56 \mathrm{c}$ & $14.22 \mathrm{~cd}$ & $13.53 \mathrm{c}$ & $1.91 \mathrm{a}$ \\
\hline 'Frøedom' & $40.15 \mathrm{c}$ & $8.24 \mathrm{c}$ & $11.14 \mathrm{~cd}$ & $19.07 \mathrm{~d}$ & $17.00 \mathrm{~cd}$ & $18.16 \mathrm{~b}$ \\
\hline 'Macfree' & $85.77 \mathrm{~d}$ & $26.22 \mathrm{~d}$ & $33.21 \mathrm{e}$ & $42.18 \mathrm{e}$ & $40.26 \mathrm{e}$ & $79.25 \mathrm{c}$ \\
\hline 'Priscilla' & $92.23 \mathrm{~d}$ & $29.18 d$ & $41.18 \mathrm{e}$ & $54.56 \mathrm{e}$ & $55.21 \mathrm{e}$ & $76.03 \mathrm{c}$ \\
\hline 'Nova Easygro' & $100.00 \mathrm{~d}$ & $40.12 \mathrm{~d}$ & $56.36 \mathrm{e}$ & $62.17 \mathrm{e}$ & $63.30 \mathrm{e}$ & $100.00 \mathrm{~d}$ \\
\hline
\end{tabular}

Mezas wituin a varisal cslume fullowed by the sams letters are not significantly different at $5 \%$ level of probability. 
Table 2

Susceptibility of apple cultivars to apple powdery mildew (Podosphaera leucotricha). Wilanów 1984

\begin{tabular}{|c|c|c|c|c|c|c|}
\hline \multirow{2}{*}{ Cultivar } & \multirow{2}{*}{$\begin{array}{l}\text { Percent of infected } \\
\text { shoots } 8.08\end{array}$} & \multicolumn{4}{|c|}{ Percent of leaf surface covered by apple powdery mildew on the days } & \multirow{2}{*}{$\begin{array}{c}\text { Percent of infected } \\
\text { fruits } 8.08\end{array}$} \\
\hline & & 6.05 & 26.06 & 16.07 & 8.08 & \\
\hline 'Primula' & $2.32 \mathrm{a}$ & $0.11 \mathrm{a}$ & $0.19 \mathrm{a}$ & $0.35 \mathrm{a}$ & $0.33 \mathrm{a}$ & 0 \\
\hline ‘Prima' & $3.01 \mathrm{a}$ & $0.16 \mathrm{a}$ & $0.22 \mathrm{a}$ & $0.40 \mathrm{a}$ & $0.51 \mathrm{a}$ & 0 \\
\hline NY $55-158-2$ & $21.41 \mathrm{~b}$ & $2.31 \mathrm{~b}$ & $4.51 \mathrm{~b}$ & $6.92 \mathrm{~b}$ & $6.70 \mathrm{~b}$ & 0 \\
\hline 'Liberty Sister' & $24.31 \mathrm{~b}$ & $4.05 \mathrm{~b}$ & $6.13 \mathrm{~b}$ & $7.31 \mathrm{~b}$ & $9.21 \mathrm{~b}$ & 0.40 \\
\hline 'Liberty' & $28.23 \mathrm{~b}$ & $3.21 \mathrm{~b}$ & $8.21 \mathrm{~b}$ & $9.44 \mathrm{~b}$ & $19.18 \mathrm{c}$ & 0.72 \\
\hline 'Novamac' & $35.21 \mathrm{c}$ & $9.83 \mathrm{bc}$ & $10.82 \mathrm{bc}$ & $17.20 \mathrm{c}$ & $23.53 \mathrm{c}$ & 3.21 \\
\hline ‘Gavin’ & $52.04 \mathrm{~d}$ & $11.22 \mathrm{c}$ & $14.35 \mathrm{c}$ & $29.33 \mathrm{~d}$ & $28.40 \mathrm{~cd}$ & 11.40 \\
\hline ‘Priam’ & $79.38 \mathrm{e}$ & $10.51 \mathrm{c}$ & $18.13 \mathrm{c}$ & $35.41 \mathrm{~d}$ & $32.77 \mathrm{~d}$ & 10.12 \\
\hline 'Florina' & $87.20 \mathrm{e}$ & $16.37 \mathrm{c}$ & $24.22 \mathrm{c}$ & $36.18 \mathrm{~d}$ & $34.51 \mathrm{~d}$ & 22.10 \\
\hline ‘Freedom' & $85.50 \mathrm{e}$ & $12.41 \mathrm{c}$ & $23.14 \mathrm{c}$ & $39.32 \mathrm{~d}$ & $36.92 \mathrm{~d}$ & 36.06 \\
\hline 'Macfree' & $100.00 \mathrm{f}$ & $30.21 \mathrm{~d}$ & $39.81 \mathrm{~d}$ & $59.22 \mathrm{e}$ & $60.05 \mathrm{e}$ & 82.03 \\
\hline 'Priscilla' & $100.00 \mathrm{f}$ & $33.50 \mathrm{~d}$ & $44.50 \mathrm{~d}$ & $61.69 \mathrm{e}$ & $62.24 \mathrm{e}$ & 89.52 \\
\hline 'Nova Easygro' & $100.00 \mathrm{f}$ & $39.22 \mathrm{~d}$ & $47.81 \mathrm{~d}$ & $67.12 \mathrm{e}$ & $65.81 \mathrm{e}$ & 100.00 \\
\hline
\end{tabular}

Means within a vertical column followed by the same letters are not significantly different at $5 \%$ level of probability. 
Table 3

Susceptibility of apple cultivar to apple powdery mildew (Podosphaera leucotricha). Wilanów 1985

\begin{tabular}{|c|c|c|c|c|c|c|}
\hline \multirow[b]{2}{*}{ Cultivar } & \multirow{2}{*}{$\begin{array}{c}\text { Percent of infected } \\
\text { shoots } \\
8.08\end{array}$} & \multicolumn{4}{|c|}{ Percent of leaf surface covered by apple powdery mildew on the days } & \multirow{2}{*}{$\begin{array}{c}\text { Percent of } \\
\text { infected fruits } \\
8.08\end{array}$} \\
\hline & & 7.06 & 27.06 & 16.07 & 8.08 & \\
\hline 'Primula' & $3.03 \mathrm{a}$ & $0.02 \mathrm{a}$ & $0.04 \mathrm{a}$ & $0.07 \mathrm{a}$ & $0.08 \mathrm{a}$ & 0 \\
\hline 'Prima' & $3.48 \mathrm{a}$ & $0.01 \mathrm{a}$ & $0.02 \mathrm{a}$ & $0.04 \mathrm{a}$ & $0.04 \mathrm{a}$ & 0 \\
\hline NY $55-158-2$ & $16.22 \mathrm{~b}$ & $0.78 \mathrm{~b}$ & $2.51 \mathrm{~b}$ & $4.18 \mathrm{~b}$ & $3.21 \mathrm{~b}$ & 0 \\
\hline 'Liberty Sister' & $18.11 \mathrm{~b}$ & $1.35 \mathrm{~b}$ & $3.91 \mathrm{~b}$ & $5.41 \mathrm{~b}$ & $6.42 \mathrm{~b}$ & $0.85 \mathrm{a}$ \\
\hline 'Liberty' & $25.18 b c$ & $2.50 \mathrm{~b}$ & $4.63 \mathrm{~b}$ & $7.30 \mathrm{~b}$ & $7.23 \mathrm{~b}$ & $0.70 \mathrm{a}$ \\
\hline 'Novamac' & $31.44 \mathrm{c}$ & $4.43 \mathrm{~b}$ & $6.98 \mathrm{~b}$ & $9.13 \mathrm{~b}$ & $11.55 \mathrm{bc}$ & $1.18 \mathrm{~b}$ \\
\hline 'Gavin' & $52.51 \mathrm{~d}$ & $13.54 \mathrm{~d}$ & $13.82 \mathrm{c}$ & $18.03 \mathrm{c}$ & $19.19 \mathrm{c}$ & $6.23 \mathrm{~b}$ \\
\hline 'Priam' & $45.30 \mathrm{~cd}$ & $7.21 \mathrm{c}$ & $13.20 \mathrm{c}$ & $14.11 \mathrm{c}$ & $16.30 \mathrm{c}$ & $4.13 \mathrm{~b}$ \\
\hline 'Florina' & $48.44 \mathrm{~cd}$ & $11.51 \mathrm{~cd}$ & $14.30 \mathrm{c}$ & $16.51 \mathrm{c}$ & $14.21 \mathrm{c}$ & $11.51 \mathrm{c}$ \\
\hline 'Freedom' & $59.25 \mathrm{~d}$ & $8.51 \mathrm{~cd}$ & $10.24 \mathrm{c}$ & $19.34 \mathrm{c}$ & $23.51 \mathrm{c}$ & $24.18 \mathrm{c}$ \\
\hline 'Macfree' & $96.17 \mathrm{e}$ & 30.56 ef & $38.14 \mathrm{~d}$ & $44.52 \mathrm{~d}$ & $40.28 \mathrm{~d}$ & $75.26 \mathrm{~d}$ \\
\hline 'Priscilla' & $100.00 \mathrm{e}$ & $28.85 \mathrm{e}$ & $40.36 \mathrm{~d}$ & $57.80 \mathrm{~d}$ & $55.40 \mathrm{~d}$ & $77.13 \mathrm{~d}$ \\
\hline 'Nova Easygro’' & $100.00 \mathrm{e}$ & $34.24 \mathrm{f}$ & $48.23 \mathrm{~d}$ & $55.33 \mathrm{~d}$ & $56.40 \mathrm{~d}$ & $100.00 \mathrm{e}$ \\
\hline
\end{tabular}

Means within a vertical column followed by ths sams letters are nst significantly different at $5 \%$ level of probability. 
Table 4

Susceptikility of apple cultivars to apple powdery mildew (Podosphaera leucotricha). Wilanów 1986

\begin{tabular}{|c|c|c|c|c|c|c|}
\hline \multirow{2}{*}{ Cultivar } & \multirow{2}{*}{$\begin{array}{c}\text { Percent of infected } \\
\text { shoots } \\
11.08\end{array}$} & \multicolumn{4}{|c|}{ Percent of leaf surface covered by apple powdery mildew on the days } & \multirow{2}{*}{$\begin{array}{c}\text { Percent of } \\
\text { infected fruits } \\
11.08\end{array}$} \\
\hline & & 5.06 & 25.06 & 18.07 & 11.08 & \\
\hline 'Primula' & 0 & 0 & 0 & $0.02 \mathrm{a}$ & $0.02 \mathrm{a}$ & 0 \\
\hline 'Prima' & 0 & $0.01 \mathrm{a}$ & $0.03 \mathrm{a}$ & $0.02 \mathrm{a}$ & $0.02 \mathrm{a}$ & 0 \\
\hline NY $55-158-2$ & $7.24 \mathrm{a}$ & $0.70 \mathrm{~b}$ & $1.26 \mathrm{~b}$ & $1.42 \mathrm{~b}$ & $1.20 \mathrm{~b}$ & 0 \\
\hline 'Liberty Sister' & $10.13 \mathrm{a}$ & $1.03 \mathrm{~b}$ & $2.41 \mathrm{~b}$ & $2.85 \mathrm{~b}$ & $2.33 \mathrm{~b}$ & 0 \\
\hline 'Liberty' & $14.22 b$ & $2.50 \mathrm{~b}$ & $4.07 \mathrm{~b}$ & $4.00 \mathrm{~b}$ & $4.02 \mathrm{~b}$ & 0 \\
\hline 'Novamac' & $13.51 \mathrm{ab}$ & $4.56 \mathrm{bc}$ & $6.22 \mathrm{~b}$ & $6.85 \mathrm{~b}$ & $6.24 \mathrm{~b}$ & 0 \\
\hline 'Gavin' & $34.22 \mathrm{c}$ & $6.12 \mathrm{c}$ & $10.05 \mathrm{c}$ & $11.56 \mathrm{c}$ & $11.39 \mathrm{c}$ & 0 \\
\hline 'Priam' & $29.81 \mathrm{c}$ & $6.31 \mathrm{c}$ & $9.26 \mathrm{c}$ & $10.12 \mathrm{c}$ & $11.05 \mathrm{c}$ & 0 \\
\hline 'Florina' & $39.44 \mathrm{c}$ & $9.22 \mathrm{c}$ & $10.45 \mathrm{c}$ & $12.31 \mathrm{c}$ & $12.08 \mathrm{c}$ & $3.91 \mathrm{a}$ \\
\hline 'Freedom' & $41.12 \mathrm{c}$ & $7.29 \mathrm{c}$ & $10.50 \mathrm{c}$ & $12.54 \mathrm{c}$ & $13.56 \mathrm{c}$ & $8.24 \mathrm{a}$ \\
\hline 'Macfroe' & $91.18 \mathrm{~d}$ & $18.23 \mathrm{~d}$ & $36.36 \mathrm{~d}$ & $48.27 \mathrm{~d}$ & $49.66 \mathrm{~d}$ & $67.82 \mathrm{~b}$ \\
\hline 'Priscilla' & $100.00 \mathrm{~d}$ & $21.35 \mathrm{~d}$ & $48.96 \mathrm{de}$ & $52.54 \mathrm{~d}$ & $56.21 \mathrm{~d}$ & $82.20 \mathrm{bc}$ \\
\hline 'Nova Easygro' & $100.00 \mathrm{~d}$ & $26.05 \mathrm{~d}$ & $52.53 \mathrm{e}$ & $54.20 \mathrm{~d}$ & $52.86 \mathrm{~d}$ & $100.00 \mathrm{c}$ \\
\hline
\end{tabular}

Means within a vertical column followad by the same letters are not significantly different at $5 \%$ level of probability. 
-158-2, 'Liberty' and a sister seedling of 'Liberty', for which the name 'Liberty Sister' was agreed on. 'Liberty', the most susceptible in this group, showing $9.44 \%$ infection on July 16,1984 , was on the border between groups of apple trees little and moderately susceptible to powdery mildew. The group of moderately susceptible cultivars was the largest and included: 'Novamac', 'Gavin', 'Priam', 'Florina' and 'Freedom'. Three cultivars, 'Priscilla', 'Nova Easygro' and 'Macfree' turned out to be very susceptible. The infection of these cultivars was so severe, that growth was stunted and fruiting declined. The few, tiny fruits were highly russested due to infection by the fungus Podosphaera leucotricha. The degree of infection of the three most susceptible cultivars exceeded $50 \%$, which expresses the average leaf area covered with powdery mildew.

\section{DISCUSSION AND CONCLUSIONS}

The observations conducted for four years have made possible a detailed comparison of the susceptibility of scab-resistant apple cultivars to the fungus, Podosphaera leucotricha. The most susceptible cultivars already showed visible signs of disease during the first year following planting. Powdery mildew did not begin to appear on the remaining cultivars until 1982. The intensity of the disease increased in 1983, the year the observations started, and reached its maximum in 1984. The decrease in the infection after the winter of $1984 / 1985$ was due to the low temperatures in January and February. This decrease was even more visible after the winter of $1985 / 1986$. The data on the lowest winter temperatures point to the strict connection between very low winter temperatures and the decrease in the severity of infection of apple trees with Podosphaera leucotricha. The temperatures noted during the consecutive seasons were as follows: $-18.5^{\circ} \mathrm{C}$ in December, $1980 ;-17.7^{\circ} \mathrm{C}$ in December, $1981 ;-16.6^{\circ} \mathrm{C}$ in February, $1982 ;-13.9^{\circ} \mathrm{C}$ in December, 1984; $-26.4^{\circ} \mathrm{C}$ in February, 1985 and $-27.2^{\circ} \mathrm{C}$ in February and $-23.8^{\circ} \mathrm{C}$ in March, 1986.

In accordance with the principle that the susceptibility of a plant to disease should be determined under optimal conditions for the pathogene, the most conclusive results are taken to be from 1984. The lack of spraying and other control methods, including cutting off diseased shoots, was the reason that the effect of low temperatures on the susceptibility of apple trees to powdery mildew was different for different cultivars. This effect was the least on the three most susceptible cultivars, 'Priscilla', 'Nova Easygro' and 'Macfree'. The severely infected shoots dried up over a considerable length, but the trees did not freeze and die, and after a somewhat less severe infection in the spring, they quickly succumbed to secondary infection by the fungus Podosphaera leucotricha. 
Much attention was paid in these observations to the methods of determining the degree of infection of apple trees by mildew. The initial trials with the use of the 6-point grading scale of $\mathrm{Knight}$ and A ls ton (1968) turned out to be deceptive in the assessment of 13 apple cultivars, since none of the studied cultivars could be assigned to grades 0,1 or 6 . After the trials made in 1983 and 1984 using three different methods, the $\mathrm{Knight}$ and Alston scale, the methods presented in the Ciba-Geigy manual (1981) and the Bor ecki and Burkowicz scale (1963), it was found that, after slight modifications depending on the separate evaluation of shoots and leaves, the last method is the most. useful and permits the easy classification of apple cultivars into groups according to their degree of susceptibility.

The percentage of diseased apple shoots, which was strictly correlated with the average area of leaves covered with mildew, also turned out to be a good indicator of the degree of susceptibility of cultivars. In 1984, this index oscillated over a wide range, since the epidemic of powdery mildew attained its high point then, from $3.32 \%$ on the cultivar 'Primula' to $100 \%$ on the 'Nova Easygro' cultivar. The fruit of apple trees practically immune and little susceptible to mildew, especially 'Prima', 'Primula' and NY 55-158-2, did not show any signs of disease at all, whereas the fruit of 'Macfree', 'Priscilla' and, especially, 'Nova Easygro' was so severely russested and tiny, that it presented no utilitarian value whatsoever.

The four point grading scale by Ald winckle (1974) was used in the interpretation of the results. This scale made it easier to draw practical conclusions. As a result of the interpretation, it was concluded that only two of the 13 studied cultivars, 'Prima' and 'Frimula', do not need fungicides for protection against powdery mildew. The spray program can be reduced in the chemical control of the following cultivars and crosses: 'Liberty', 'Liberty Sister', and NY 55-158-2. According to the applied system of classification, the susceptibility of these cultivars is similar to that of 'Spartan', 'Red Delicious' and 'Boskoop'. The cultivars 'Novamac', 'Priam', 'Florina', 'Freedom' and 'Gavin' should be controlled with a standard spray program. The most susceptible cultivars however, 'Priscilla', 'Nova Easygro' and 'Macfree', need a more intense chemical control program.

In the evaluation of apple cultivars resistance to diseases, the main aim of breeding for resistance, which is the complete resignation from or significant limitation of the use of fungicides, must be taken into account. Using such rigorous criteria, the cultivars: 'Priscilla', 'Nova Easygro' and 'Macfree' must be disqualified since they do not fulfill the set requirements. Two of the most valuable cultivars in the group of moderately susceptible cultivars, 'Novamac' and 'Freedom', require fur- 
ther detailed evaluation, especially determination of the effectiveness of mildew control without the use of fungicides. The cultivars whose cultivation with significant reduction of the frequency of spraying seems possible are: 'Liberty' and 'Liberty Sister'. The cross, NY 55-158-2 also belongs to this group, but is a relatively primitive apple tree.

\section{REFERENCES}

Ald winckle H. S., 1974. Field susceptibility of 51 apple cultivars to apple scab and apple powdery mildew. Pl. Dis. Rep. 58: 625-629.

A ld winckle H. S., 1979. Resistance of scab-resistant apple cultivars and selections to the most important diseases in New York. Personal communication.

Alston F. H., 1969. Response of apple cultivars to mildew, Podosphaera leucotricha. Rep. East. Mall Res. Sta. for 1968 pp. 133-135.

Borecki Z., Burkowicz A., 1963. Badania nad skutecznością różnych fungicydów w zwalczaniu mączniaka jabloniowego i parcha jabłoniowego. Prace Inst. Sad. 7: 197-206.

Brown A. G., 1959. The inheritance of mildew resistance in progenies of the cultivated apple. Euphytica 8: 81-88.

Butt D. J., 1979. An apple mildew assessment method for use in supervised control. Rep. East Mall. Res. Sta. for 1978 pp. 211-214.

Dayton D. F., 1977. Genetic immunity to apple mildew invited by Podosphaera leucotricha. Hort. Sci. 12: 225.226.

Heald F. D., 1933. Manual of plant diseases. 2nd ed., McGraw-Hill Book, New York pp. 935.

Knight R. L., Alston F. H., 1968. Sources of field immunity to mildew (Podosphaera leucotricha) in apple. Can. Journ. Gen. Cyt. 10: 294-298.

Lamb R. C., Ald winckle H. S., Way R. D., Terry D. E., 1978. Liberty, a new disease resistant apple. N. Y. Food and Life Sc. Bull. p. 73.

Manual for field trials in plant protection. Documenta Ciba-Geigy 2nd ed., 1981.

McIntosh D. L., Lapins K., 1966. Differences in susceptibility to apple powdery nildew observed in McIntosh clone after exposure to ionizing radiation. Can. Journ. Plant Sci, 46: 619-623.

IM is i c P. D., 1966. Investigations on the susceptibility of apple varieties to Podosphaera leucotricha (Ell. et Ev.) Salm. Arch. poljopr. Nauk. Tech. 19: 130-150 .

Mowry J. B., 1965. Inheritance of susceptibility of apple to Podosphaera leucotricha. Phytopath. 65: 76-78.

Rejm an A., 1976. Pomologia. PWRiL, Warszawa pp. 41.

Schander H., 1958. Untersuchungen zur Entwicklung von Frühselektionsmethoden für die Apfelzuchtung. II. Über Frühselektion auf Rezistenz gegen Apfelmehltau (Podosphaera leucotricha), über, die Anfälligkeit von Apfelsorten und über die Vererbung der Anfälligkeit. Züchter 28: 105-132.

Sicbs E., 1959. Ergebnisse zu Problemen des Mehltaus und Mehltaurezistenz des Apfels. Phytopath. Zeitschr. 34: 86-102.

Spraque R., 1953. Powdery mildew of the apple. U.S. Dep. Agr. Yearbook, 1953 pp. 667-670.

W a tkins R., 1974. Fruit breeding. Rep. East. Mall. Res. Sta. for 1973 pp. 121-130 . 


\section{WRAŻLIWOSC PARCHOODPORNYCH ODMIAN JABłONI NA MAZCZNIAKA PRAWDZIWEGO [PODOSPHAERA LEUCOTRICHA (ELL. ET EV.) SALMON]}

\section{Streszczenie}

W latach 1983-1986 zbadano w warunkach polowych wrażliwość 13 parchoodpornych odmian jabłoni na mączniaka prawdziwego jabłoni (Podosphaera leucotricha). Wyodrębniono cztery grupy odmian o różnym stopniu wrażliwości. Żadna z odmian jabłoni nie wykazywała całkowitej odporności na mączniaka. Do odmian porażonych $\mathrm{w}$ stopniu bardzo słabym, praktycznie odpornych, należały 'Prima' i jej siostrzana siewka 'Primula'. W grupie jabloni mało wrażliwych znalazły się: NY 55-158-2, 'Liberty' i siostrzana siewka 'Liberty'. Srednio wrażliwe były: 'Novamac', 'Gavin', 'Priam', 'Florina' i 'Freedom', a bardzo wrażliwe: 'Macfree', 'Priscilla' i 'Nova Easygro'. Uznano, że odmiany 'Prima' i 'Primula' nie wymagają opryskiwania fungicydami przeciwko mączniakowi. W ochronie odmian mało wrażliwych można stosować ograniczony program opryskiwań, a w ochronie odmian średnio wrażliwych program standardowy. Bardziej intensywny program opryskiwań jest niezbędny $w$ ochronie odmian zaliczonych do bardzo wrażliwych. 